This item was submitted to Loughborough's Research Repository by the author.

Items in Figshare are protected by copyright, with all rights reserved, unless otherwise indicated.

\title{
Guest editorial special issue on selected papers from EAPPC 2014
}

PLEASE CITE THE PUBLISHED VERSION

http://dx.doi.org/10.1109/TPS.2015.2477555

PUBLISHER

(c) IEEE

VERSION

AM (Accepted Manuscript)

LICENCE

CC BY-NC-ND 4.0

REPOSITORY RECORD

Redondo, Luis M. S., Hamid Hosseini, Bucur M. Novac, and Xinjie Yu. 2019. "Guest Editorial Special Issue on Selected Papers from EAPPC 2014". figshare. https://hdl.handle.net/2134/20459. 


\section{Guest Editorial IEEE Transactions on Plasma Science Special Issue for Selected Papers from EAPPC 2014}

This is the Special Issue on selected papers from the 5th Euro-Asian Pulsed Power Conference in Kumamoto, Japan, from 8-12 September, 2014. This Special Issue continues a tradition of chronicling the latest advances in pulsed-power science and technology.

Since 2006, the Euro-Asian Pulsed Power Conference has been a forum of excellence for the presentation and discussion, among scientists and engineers, of pulsed power science and technology and civil applications. The success of the meeting has been demonstrated once more time from the number of international participants and quality papers. In 2014 EAPPC there were 231 submitted abstracts from 21 countries, of which $71 \%$ were from Japan, China and Korea.

The manuscripts presented in this Special Issue represent the state-of-art of Pulsed Power Science and Technology and Applications, and show without doubt that Pulsed Power is nowadays, already, contributing to the well-being of the people, as shown by the considerably growth of papers on biological, medical and environmental applications.

As Guest Editors we would like to express our gratitude to the authors for their contributions to this Special Issue and in adding fundamental understanding of this field and its applications. In addition, we would like to thank the referees for their volunteer efforts in reviewing the manuscripts, and their many suggestions, which enhanced the quality of the papers. We would also like to extend our gratitude to the Editor-in-Chief, Steve Gitomer, for his many kindnesses, his patience, and his vigilance. Finally, we truly appreciate the work of Weihua Jiang as Senior Editor for Pulsed Power Science and Technology. His continued excellent guidance of this Special Issue made the job of the Guest Editors much easier and the quality of the Special Issue much better.

Luis M. S. Redondo, Guest Editor

Lisbon Superior Engineering Institute

Lisbon, 1959-007 Portugal

(email: lmredondo@deea.isel.ipl.pt)

Hamid Hosseini, Guest Editor

Bioelectrics Department, Institute of Pulsed Power Science

Kumamoto University

Kumamoto 860-8555, Japan

(email: hosseini@kumamoto-u.ac.jp) 


\author{
Bucur Novac, Guest Editor \\ School of Electronic, Electrical and Systems Engineering \\ Loughborough University \\ Leicestershire LE11 3TU, UK \\ (email: b.m.novac@lboro.ac.uk) \\ Xinjie Yu, Guest Editor \\ Department of Electrical Engineering \\ Tsinghua University \\ Beijing 100084, China \\ (email: yuxj@tsinghua.edu.cn)
}

